\title{
A Single Locus Leads to Resistance of Arabidopsis thaliana to Bacterial Wilt Caused by Ralstonia solanacearum Through a Hypersensitive-like Response
}

\author{
Gan-Der Ho and Chang-Hsien Yang
}

Graduate Institute of Agricultural Biotechnology, National Chung Hsing University, Taichung, Taiwan 40227 ROC. Accepted for publication 22 April 1999.

\begin{abstract}
Ho, G.-D., and Yang, C.-H. 1999. A single locus leads to resistance of Arabidopsis thaliana to bacterial wilt caused by Ralstonia solanacearum through a hypersensitive-like response. Phytopathology 89:673-678.

Strains of Ralstonia solanacearum have been shown to cause bacterial wilt in some, but not all, ecotypes of Arabidopsis thaliana. We demonstrate here that after inoculation of the leaves of resistant ecotype S96 with $R$. solanacearum strain Ps95 necrosis around the inoculation site rapidly appeared and no further symptoms developed in the plant. Leaves of susceptible ecotype N913 completely wilted 7 days after inoculation with Ps95, and symptoms spread systemically throughout the whole plant within 2 weeks

after inoculation. These results suggest that the resistance of Arabidopsis S96 to $R$. solanacearum is due to a response similar to the hypersensitive response (HR) observed in other plant diseases. Northern blot analysis of the expression of defense-related genes, known to be differentially induced during the HR in Arabidopsis, indicated that pathogenesis-related protein $P R$-1, glutathione S-transferase (GST1), and $\mathrm{Cu}, \mathrm{Zn}$ superoxide dismutase (SOD) mRNAs increased significantly in S96 leaves between 3 to $12 \mathrm{~h}$ after infiltration with Ps95. The induction of these genes in susceptible ecotype N913 by Ps95 was clearly delayed. Genetic analysis of crosses between resistant ecotype S96 and susceptible ecotype N913 indicated that resistance to Ps95 is due to a single dominant locus.
\end{abstract}

Ralstonia solanacearum, a bacterial plant pathogen, causes a serious wilt disease and severe losses to many agricultural crops throughout the world (14). To develop useful strategies to control this disease, it is very important to investigate mechanisms of plant resistance. Arabidopsis thaliana (L.) Heynh. has been successfully used as a model host plant for several bacterial pathogens including $R$. solanacearum $(10,18,27,34)$. A variety of disease responses were observed among different Arabidopsis ecotypes 2 weeks after inoculation with different strains of $R$. solanacearum. Both susceptible and resistant ecotypes of Arabidopsis were identified (34). The susceptible ecotypes develop systemic wilt, whereas the resistant ecotypes remain asymptomatic after infection. The degree of pathogenicity of different strains of $R$. solanacearum was correlated with the rapid distribution of the bacterium throughout the shoot of susceptible plants. This suggests that the ability of resistant Arabidopsis ecotypes to limit the multiplication and movement of $R$. solanacearum through the plant is a major factor in their disease resistance (34).

The restriction of various pathogens to the inoculation site in resistant interactions has been widely reported $(3,7,12,23,30)$. A rapid necrotic response, called the hypersensitive response (HR), often results from gene-for-gene recognition (16), although the molecular mechanisms of HR elicitation are still unclear. Since resistance to bacterial wilt in different tomato varieties has been demonstrated genetically to be controlled by quantitative trait loci $(1,9,26,31,32)$, the basis of the resistance of Arabidopsis to $R$. solanacearum provides a useful model system.

In this study, we investigated the mechanism of resistance of Arabidopsis ecotype S96 to $R$. solanacearum. Our results demonstrate that rapid cell death, similar to a HR, occurred at the inoculation site and was strongly correlated with the resistance. A ne-

Corresponding author: C.-H. Yang; E-mail address: chyang@dragon.nchu.edu.tw

Publication no. P-1999-0602-01R

(C) 1999 The American Phytopathological Society crotic zone around the inoculation or infiltration site was observed only in resistant plants, whereas systemic infection developed in susceptible plants.

This hypersensitive-like response is very similar to that observed in Arabidopsis plants infected with other bacterial pathogens, in which bacterial growth is either reduced or directly limited to the site of inoculation $(18,27)$. Single resistance genes are involved in the resistance of Arabidopsis to Pseudomonas syringae (RPS2 and $R P M 1)$ and Xanthomonas campestris $(R X C)(3,6,12,18,23,27)$. Here, we analyze the genetic basis of the resistance in Arabidopsis to $R$. solanacearum. As in other HR systems, a single dominant locus, identified in resistant ecotype S96, is genetically linked for this hypersensitive-like response and resistance to $R$. solanacearum strain Ps95. This finding suggests that the Arabidopsis- $R$. solanacearum interaction could be an excellent model system that could lead to the cloning of additional resistance genes in the future.

\section{MATERIALS AND METHODS}

Plant growth conditions. Seeds of Arabidopsis ecotypes N913 and S96 were obtained from the Arabidopsis Biological Resource Center, The Ohio State University, Columbus. Seeds were sterilized and placed on agar plates containing $1 / 2 \times$ Murashige \& Skoog medium (24), kept at $4^{\circ} \mathrm{C}$ for 2 days and then germinated in growth chambers under long-day conditions (16-h light/8-h dark) for 10 days before being transplanted to the greenhouse. The light intensity of the growth chambers was $150 \mu \mathrm{E} \mathrm{m}^{-2} \mathrm{~s}^{-1}$. Seedlings were transplanted to soil and grown in greenhouses for different times before bacterial inoculation. The greenhouses were maintained at $22^{\circ} \mathrm{C}$ with $16 \mathrm{~h}$ of light for long-day conditions.

Bacterial inoculation. The Taiwanese strains of $R$. solanacearum, Rd15 (from radishes) and Ps95 (from tomatoes), used in this study are both race 1 and virulent to sweet pepper, eggplant, and tobacco (34). Bacteria were grown on a tetrazolium chloride selective agar medium (17) at $28^{\circ} \mathrm{C}$ for 4 days before inoculation. Two methods were used to introduce bacteria into the leaves of 
Arabidopsis. In the first method, 17-day-old plants were inoculated by puncturing the surface of the rosette or cauline leaves with a needle dipped into a bacterial colony. The number of bacteria used for each needle puncture was determined by a serial dilution plating and was approximately $10^{8} \mathrm{CFU}$ per plant. In the second method, bacterial suspensions $\left(10^{8} \mathrm{CFU} / \mathrm{ml}\right)$ were infiltrated with a syringe into a $1-$ to $2-\mathrm{cm}^{2}$ area of the leaf through a hole made by a needle puncture. The infected plants were grown under long-day conditions (16-h light/8-h dark) at $25^{\circ} \mathrm{C}$ in a growth chamber until symptoms appeared. Inoculations using each method were done three times using at least five plants of each ecotype for each strain in each experiment.

RNA gel blot analysis. For RNA isolation, $100 \mathrm{mg}$ of fresh leaf tissue was homogenized with $1 \mathrm{ml}$ of homogenization solution (ULTRASPEC RNA isolation system; BIOTECX Company, Hous- ton). The homogenate was stored at $4{ }^{\circ} \mathrm{C}$ for $5 \mathrm{~min}$ and $0.2 \mathrm{ml}$ of chloroform per $1 \mathrm{ml}$ of homogenate was added. The samples were covered tightly, shaken vigorously for $15 \mathrm{~s}$, and kept on ice at $4^{\circ} \mathrm{C}$ for $5 \mathrm{~min}$. After centrifugation for $15 \mathrm{~min}$ at $12,000 \times g\left(4^{\circ} \mathrm{C}\right)$, an equal volume of isopropanol was added to the aqueous phase and samples were stored for $10 \mathrm{~min}$ at $4^{\circ} \mathrm{C}$. RNA was precipitated by centrifugation for $10 \mathrm{~min}$ at $12,000 \times \mathrm{g}\left(4^{\circ} \mathrm{C}\right)$, washed twice with $75 \%$ ethanol, and centrifuged for $5 \mathrm{~min}$ at $7,500 \times g\left(4^{\circ} \mathrm{C}\right)$. RNA was dried under vacuum and resuspended in diethylpyrocarbonatetreated water.

For northern hybridizations, $5 \mu \mathrm{g}$ of total RNA was electrophoresed in formaldehyde agarose gels (2) and transferred to Hybond $\mathrm{N}+$ membranes (Amersham International, Buchinghamshire, United Kingdom). The membranes were prehybridized for $30 \mathrm{~min}$, hybridized with a ${ }^{32} \mathrm{P}$-labeled DNA probes overnight in the same solu-

TABLE 1. Oligonucleotide primers used for the polymerase chain reaction (PCR) amplification of DNA probes

\begin{tabular}{|c|c|c|c|c|}
\hline Gene & Sense primer & Antisense primer & PCR product $(b p)^{a}$ & Reference \\
\hline$P R-1$ & GTAGGTGCTCTTGTTCTTCCC & CACATAATTCCCACGAGGATC & 420 & 33 \\
\hline GST1 & ATGGCAGGAATCAAAGTTTCG & CAAGACTCATTATCGAAGATTAC & 1,016 & 29 \\
\hline $\mathrm{Cu}, \mathrm{Zn} S O D$ & GCGAAAGGAGTTGCAGTTTTGAACA & ACACGGCCGCCTGCGTTTCCAGTAG & 1,100 & 15 \\
\hline
\end{tabular}

a Genomic DNA as a template for PCR reaction.
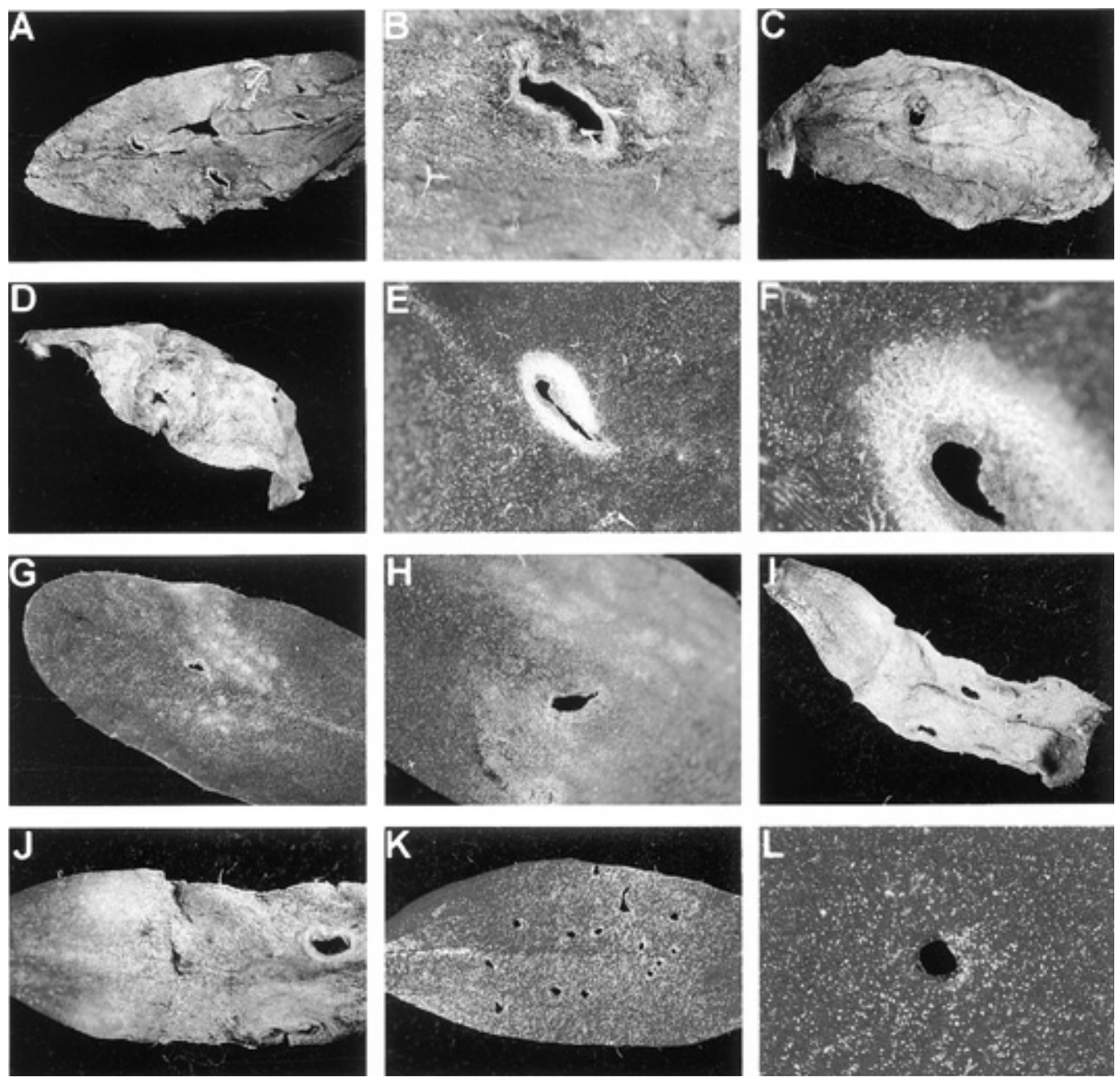

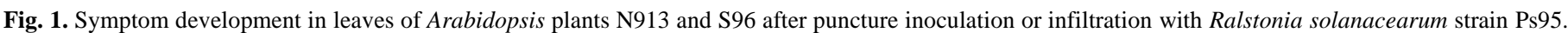

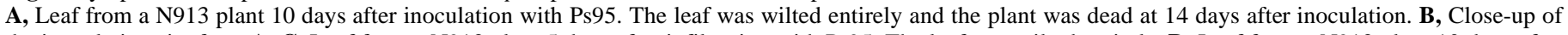

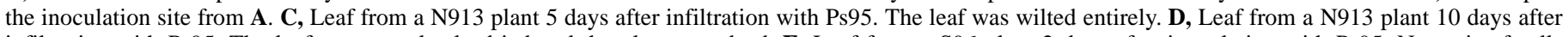

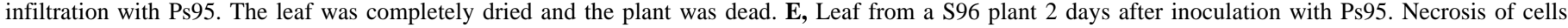

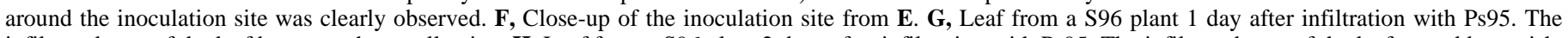

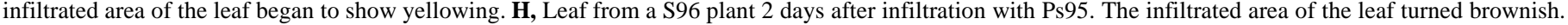

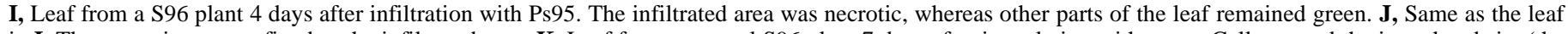

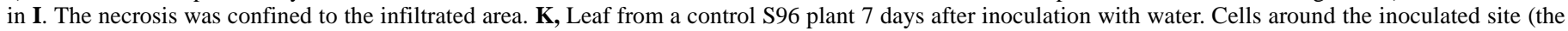
hole) have no sign of any damage or necrosis. $\mathbf{L}$, Close-up of the inoculation site from $\mathbf{K}$, which is distinct from that observed in $\mathbf{E}$. 
tion $\left(0.25 \mathrm{M} \mathrm{Na}_{2} \mathrm{HPO}_{4}, \mathrm{pH} 7.2\right.$, and $7 \%$ sodium dodecyl sulfate [SDS]), and then washed twice each in solution $1\left(20 \mathrm{mM} \mathrm{Na}_{2} \mathrm{HPO}_{4}\right.$, $\mathrm{pH} 7.2$, and 5\% SDS ) and solution $2\left(20 \mathrm{mM} \mathrm{Na}_{2} \mathrm{HPO}_{4}, \mathrm{pH} 7.2\right.$, and $1 \%$ SDS) for 30 min per wash. The blots were then air-dried, covered with plastic wrap, and autoradiographed. The DNA probes specific for defense genes PR-1 (420 bp), GST1 (1,016 bp), and $\mathrm{Cu}, \mathrm{Zn} S O D(1,100 \mathrm{bp})$ were amplified through polymerase chain reactions (PCRs). About 50 ng of genomic DNA was used as a template for 35 cycles of PCR amplification. The reaction mixture contained $10 \mathrm{mM}$ Tris- $\mathrm{HCl}$ ( $\mathrm{pH} 8.3$ ), $50 \mathrm{mM} \mathrm{KCl}, 1.5 \mathrm{mM} \mathrm{MgCl}$, $0.01 \%$ gelatin, $200 \mu \mathrm{M}$ of each deoxynucleoside triphosphate, and $0.1 \mu \mathrm{M}$ of each oligonucleotide primer in a volume of $50 \mu \mathrm{l}$. The denaturing step was at $94^{\circ} \mathrm{C}$ for $1 \mathrm{~min}$, the annealing step was at $55^{\circ} \mathrm{C}$ for $2 \mathrm{~min}$, and the extension step was at $72^{\circ} \mathrm{C}$ for $2 \mathrm{~min}$. The primers used for PCR amplification are listed in Table 1.

Genetic analysis. To analyze the genetic basis of resistance, plants of ecotype N913 (susceptible to Ps95) were crossed with plants of ecotype S96 (resistant to Ps95). $F_{1}$ plants were self-pollinated, and the $\mathrm{F}_{2}$ progeny were inoculated with Ps95 by infiltration of leaves at different developmental stages. The resistant and susceptible plants were counted. To further confirm the result, backcrosses were also made $\left(F_{1} \times S 96\right.$ and $\left.F_{1} \times N 913\right)$ and the progeny were tested for resistance to Ps95.

\section{RESULTS}

Resistance of Arabidopsis to $R$. solanacearum is associated with a hypersensitive-like response. Strains of $R$. solanacearum caused bacterial wilt symptoms on Arabidopsis plants similar to those observed in solanaceous crops, i.e., leaf wilting, discoloration, leaf drop, stunting, and finally permanent wilting and death (34). When bacteria were inoculated directly into the inflorescence stem of susceptible plants, as reported previously, it was difficult to observe any disease response at the infection site. In this study, we inoculated bacteria into leaves by needle puncture or infiltration and clear differences between susceptible and resistant ecotypes were observed. For example, Rd15 caused severe symptoms in both ecotypes N913 and S96, whereas Ps95 caused symptoms only in ecotype N913 and not in S96. In all susceptible cases, symptom development was slightly slower than previously reported for inflorescence inoculation. With Rd15, symp-

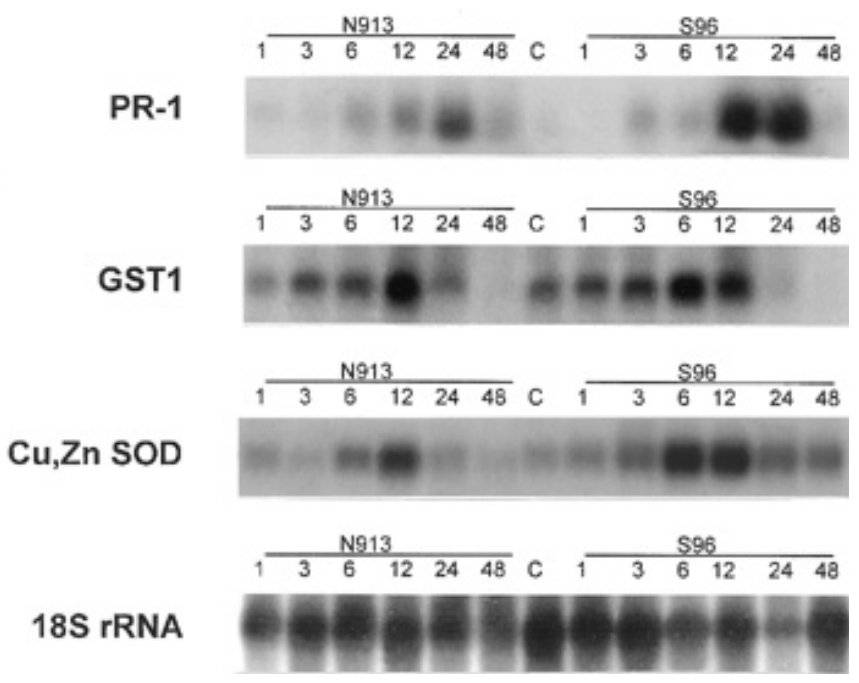

Fig. 2. Northern blot analysis showing the induction of $P R-1, G S T 1$, and Cu,Zn SOD mRNAs in leaves of Arabidopsis S96 and N913 plants after infiltration with Ralstonia solanacearum strain Ps95. Total RNA was extracted from the infiltrated area of leaves from three different S96 or N913 plants at different times after infiltration $(1,3,6,12,24$, and $48 \mathrm{~h}$ ) with Ps95. About $5 \mu \mathrm{g}$ of mRNA was used for each sample. Time in hours after infiltration is indicated above the blots. C indicates the noninfiltrated control plant. 18S rRNA served as an internal control. Each experiment was repeated twice with similar results. toms appeared after 1 to 3 days in the inoculated leaves of both S96 and N913 plants and the leaves were completely wilted by 7 days after infection. Symptoms rapidly spread to other parts of the plant, and plants were completely wilted by 10 days after infection. This is slightly later than with inflorescence inoculation, in which the plants completely wilted by 7 days after infection (34).

Leaves of N913 plants inoculated with Ps95 showed symptoms after 3 to 5 days and were completely wilted by 10 days after infection (Fig. 1A and B). Symptoms spread slower than in plants
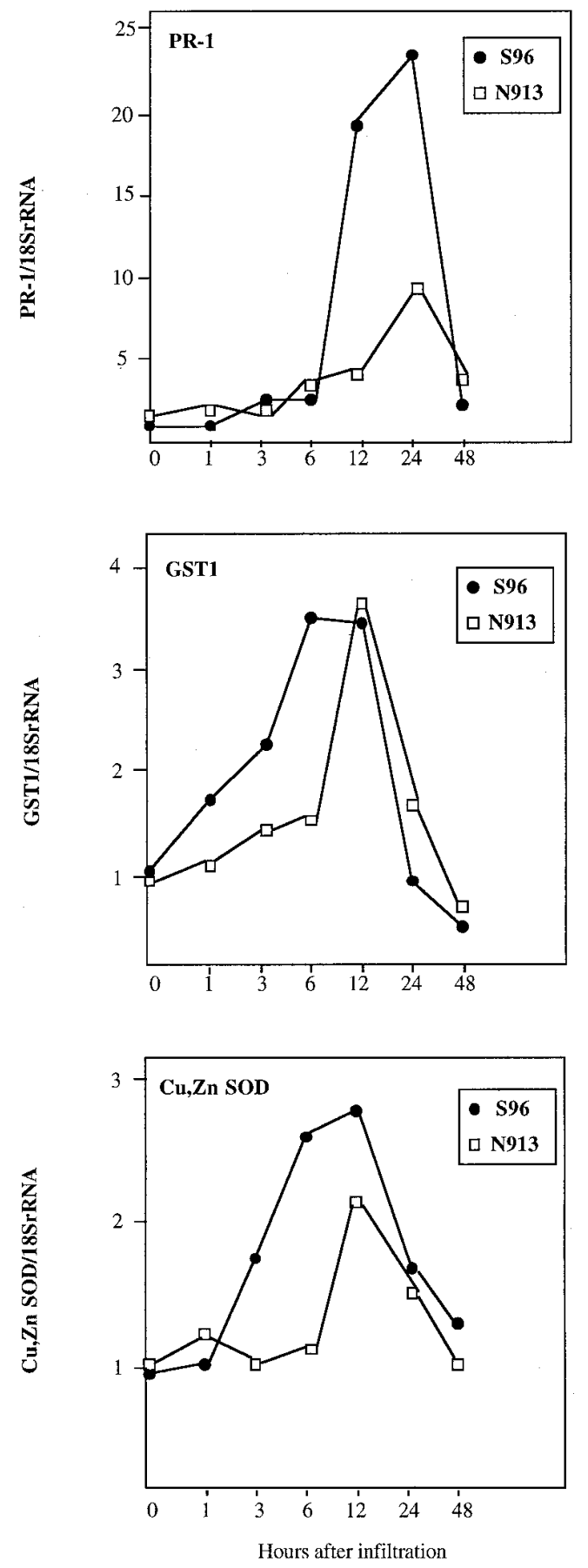

Fig. 3. Induction of $P R-1, G S T 1$, and $\mathrm{Cu}, \mathrm{Zn} S O D$ in Arabidopsis ecotypes S96 and N913 at different times after infiltration with Ralstonia solanacearum strain Ps95. The strength of the signals in northern blots (Fig. 2) were measured with a PhosphorImager (Fuji Photo Film Co., Tokyo). The values of the hybridization signal obtained for $P R-1, G S T 1$, and Cu,Zn $S O D$ were normalized to the values obtained for the $18 \mathrm{~S}$ rRNA control probe for each time point. The normalized value for noninoculated control at time 0 was set equal to 1 , and the resulting relative values for each time point were plotted. Data points are the means of two independent experiments that showed similar results. 
infected with Rd15, and plants were completely wilted by 14 days after infection. Similar symptom development was observed when bacteria were introduced into the leaves by infiltration (Fig. 1C and D).

In the resistant interaction, S96 inoculated with Ps95, wilt symptoms were not observed in any part of the plants by 14 days after inoculation. Interestingly, after inoculation of the bacteria by direct needle puncture into the leaves, the tissue surrounding the inoculation sites became necrotic as early as 1 day after inoculation. These cells completely died 2 to 3 days after inoculation and no further necrosis developed (Fig. 1E and F). This rapid necrotic response prevented further disease development and appeared to be a HR. Similar results were observed when bacteria were infiltrated into the leaves. The infiltrated area became chlorotic within 1 day (Fig. 1G) and then turned brownish (Fig. 1H) and necrotic, whereas other parts of the leaf remained green (Fig. 1I and J). The visible necrosis clearly corresponded to the infiltrated zone (Fig. 1J). Control leaves inoculated or infiltrated with water remained green and symptomless (Fig. $1 \mathrm{~K}$ and $\mathrm{L}$ ), indicating that the necrosis was caused by the bacterial infection and not by wounding.

$P R-1, G S T 1$, and $\mathrm{Cu}, \mathrm{Zn} S O D$ mRNAs were differentially induced in resistant and susceptible Arabidopsis leaves after infiltration with Ps95. To investigate if the expression of defense-related or pathogenesis-related genes in Arabidopsis could be induced by infection with $R$. solanacearum, mRNA from leaves of Arabidopsis plants S96 and N913 after infiltration with Ps95 was isolated at various times and assayed using northern hybridization. As shown in Figures 2 and 3, the level of $P R-1$ transcripts increased significantly in S96 $12 \mathrm{~h}$ after inoculation (about 20-fold more than in noninoculated control plants). The amount of $P R-1$ mRNA remained at the same level for $24 \mathrm{~h}$ after infiltration and decreased to a basal level at $48 \mathrm{~h}$. In contrast to S96, $P R-1$ transcripts in N913 only increased about eightfold over controls by $24 \mathrm{~h}$ after infiltration with Ps95. The amount of $P R-1$ mRNA declined to half at $48 \mathrm{~h}$ after infiltration. This result clearly indicates that $P R-1$ mRNA was induced earlier and more abundantly in resistant plants than in susceptible plants. In leaves infiltrated with water as controls, the amount of $P R-1$ mRNA was detected at a basal level similar to that of untreated leaves. This indicated that the induction of mRNA was caused by the bacterial infection and not by wounding.

The induction of the GST1 gene in infiltrated plants was similar to that observed for $P R-1$ as shown in Figures 2 and 3. In S96 plants infiltrated with Ps95, GST1 transcripts peaked at $6 \mathrm{~h}$ after infiltration, reaching a level three- to fourfold higher than in noninoculated controls. The amount of GST1 mRNA remained at the same level until $12 \mathrm{~h}$ and then decreased to a basal level at $48 \mathrm{~h}$. In the susceptible interactions, the induction of GST1 transcripts was delayed in N913 plants at $12 \mathrm{~h}$ after infiltration with Ps95. The GST1 mRNA decreased gradually to a basal level by $48 \mathrm{~h}$ after infiltration. In control plants, the GST1 transcripts were not induced by infiltration with water as shown in Figure 2.

$\mathrm{Cu}, \mathrm{Zn} S O D$ was also differentially induced in resistant and susceptible ecotypes after infiltration with Ps95. As shown in Figures 2 and 3, Cu,Zn SOD transcripts were induced in S96 plants after only $3 \mathrm{~h}$ and peaked at $12 \mathrm{~h}$; maximum levels were two- to threefold more than in control plants. The amount of $\mathrm{Cu}, \mathrm{Zn} S O D$ mRNA decreased between 24 and $48 \mathrm{~h}$ after infiltration. In the susceptible interaction, the induction of $\mathrm{Cu}, \mathrm{Zn} S O D$ transcripts was delayed in N913 plants at $12 \mathrm{~h}$ after infiltration with Ps95. The Cu,Zn SOD mRNA decreased to a basal level at $48 \mathrm{~h}$.

Genetic analysis of resistance to $R$. solanacearum Ps95 in ecotype S96. Since different ecotypes of Arabidopsis exhibit differential responses to Ps95 (34), genetic analysis of the nature of this resistance and the identification of any resistance genes are important. Crosses between resistant ecotype S96 and susceptible ecotype N913 were made, and $\mathrm{F}_{2}$ segregating populations were obtained. As shown in Table 2, after infiltration of Ps95 into the leaves of 10130 -day-old N913 $\times$ S96 $\mathrm{F}_{2}$ plants, 76 of them showed a resistant response by only producing necrosis at the infiltration site (Fig. 4, right). The remaining $25 \mathrm{~F}_{2}$ plants showed a susceptible phenotype and developed typical systemic wilt symptoms by 7 days after infiltration (Fig. 4, left). This 3:1 ratio of resistant to susceptible plants suggests that a dominant resistance locus is present in ecotype S96 and is absent in ecotype N913. To confirm this result, younger $F_{2}$ plants were infiltrated with Ps95 and symptom development was recorded. As shown in Table 2, a clear 3:1 ratio of resistant to susceptible plants was observed again in both 10- and 20 -day-old $F_{2}$ populations. When the data from these three independent experiments were combined, a more significant segregation ratio for confirming linkage of a hypersensitive-like response to wilt symptoms was obtained $\left(265: 86, X_{3: 1}^{2}=0.0443, P>0.5\right)$.

To confirm single-locus inheritance, further genetic analysis was performed. Whereas 16 progeny from a first backcross, $\mathrm{F}_{1}(\mathrm{~N} 913 \times$ S96) $\times$ S96, were all resistant, 7 progeny from a second backcross, $\mathrm{F}_{1}(\mathrm{~N} 913 \times \mathrm{S} 96) \times \mathrm{N} 913$, segregated into three resistant and four susceptible progeny. All of these backcross progeny plants were then self-fertilized and the phenotypes of their progenies were analyzed. From the first backcross, 7 out of the above 16 individuals gave a 3:1 ratio of resistant to susceptible progeny and 9 out of 16 gave progeny that were all resistant $\left(7: 9, X_{1: 1}^{2}=0.25, P>0.5\right)$. From the second backcross, three resistant individuals gave a 3:1 ratio of resistant to susceptible progeny and four susceptible individuals gave progeny that were all susceptible $\left(3: 4, X_{1: 1}^{2}=0.14, P>0.5\right)$. This result strongly supports the conclusion that resistance is due to a single dominant gene and is not influenced by plant age. Ecotype N913 clearly lacks resistance to any of the tested strains of $R$. solanacearum and, therefore, is highly susceptible to infection by Ps95.

\section{DISCUSSION}

In our previous study, Arabidopsis was demonstrated to be a host plant for $R$. solanacearum and both resistant and susceptible ecotypes were identified (34). Bacteria were unable to multiply and spread throughout the resistant plants (34). Using the leaf-inoculation procedures described here, development of wilting symptoms was identical to that observed after inoculation of the inflorescence stem. Leaf inoculation provides an easier and more efficient way to study the interactions between Arabidopsis and $R$. solanacearum.

In resistant plants, rapid necrosis of cells adjacent to the infection site in the leaves was correlated with reduced movement of the bacteria away from the inoculation site. This observation supports the notion that a mechanism limiting the spread of bacteria exists in resistant plants (34) and it should function in both stem and leaf the same way. The necrosis of cells caused by this mech-

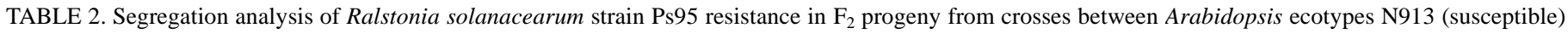
and S96 (resistant)

\begin{tabular}{|c|c|c|c|c|c|c|}
\hline Cross & Inoculated stage ${ }^{a}$ & Resistant $^{\mathrm{b}}$ & Susceptible $^{c}$ & Expected ratio (R:S) & $X^{2}$ & $P$ \\
\hline N913 × S96 & 10 & 99 & 32 & $3: 1$ & 0.023 & 0.88 \\
\hline $\mathrm{N} 913 \times \mathrm{S} 96$ & 20 & 90 & 29 & $3: 1$ & 0.0252 & 0.87 \\
\hline $\mathrm{N} 913 \times \mathrm{S} 96$ & 30 & 76 & 25 & $3: 1$ & 0.0033 & 0.96 \\
\hline
\end{tabular}

a Indicates the days after germination when plants were inoculated with bacteria.

b Resistant $(\mathrm{R})=$ Ten days after infiltration with strain Ps95, only cell death in the infiltrated area of the leaf was observed; the plant was completely healthy.

c Susceptible $(S)=$ Ten days after infiltration with strain Ps95, the infiltrated leaf was wilted entirely and the plant showed severe symptoms. 
anism is similar to the HR reported in resistant responses of many plants including the interactions between Arabidopsis and $P$. syringae $(3,12,23)$, in which the inoculation of certain $P$. syringae strains on resistant Arabidopsis ecotypes caused cell death and limitation of bacterial growth and spread. In addition, certain strains of $R$. solanacearum have been reported to be able to induce a HR in tobacco leaves after infiltration $(4,8)$.

It is well known that certain defense genes are induced during the HR caused by various pathogens and may be involved the inhibition of pathogen growth $(5,8,13,19,20-22,25,28,29)$. In general, these defense genes are induced in both incompatible and compatible reactions, but their expression is usually delayed or weaker in the susceptible response $(11,33)$. In this study, we show that the expression of three defense genes, PR-1, GST1, and $\mathrm{Cu}, \mathrm{Zn} S O D$, is induced by infection with Ps95 in both resistant (S96) and susceptible (N913) Arabidopsis ecotypes. However, the induction of these three genes is earlier and stronger in S96 than in N913 plants. Their expression pattern provides additional evidence that the resistance of S96 to Ps95 is an elicited response similar to the HR.

Arabidopsis resistance genes such as RPS 2 and $R P M 1$ that confer resistance to $P$. syringae have been identified and cloned $(3,12$, 23). Like many other genes involved in a HR, RPS 2 and RPM1 are both inherited as single dominant loci. Since the HR-like resistance observed in ecotype S96 also appears to be inherited as a single dominant trait, we propose that infection by Ps95 triggers a mechanism similar to a HR, which is conditioned by the resistance locus identified here. This mechanism causes rapid induction of defense genes and necrosis at the inoculation site, which prevents the further spread of the bacteria in the resistant plants. In susceptible plants (N913), the absence of this locus results in the delay of defense gene expression. The pathogen then multiplies rapidly and spreads throughout the plant, resulting in death. To confirm this observation and investigate the resistance mechanism, efforts are underway to analyze more crosses made from various combinations between resistant and susceptible ecotypes and to test the allelism of the resistance genes identified in different ecotypes. Further mapping and cloning of the resistance genes identified in S96 are also in progress.

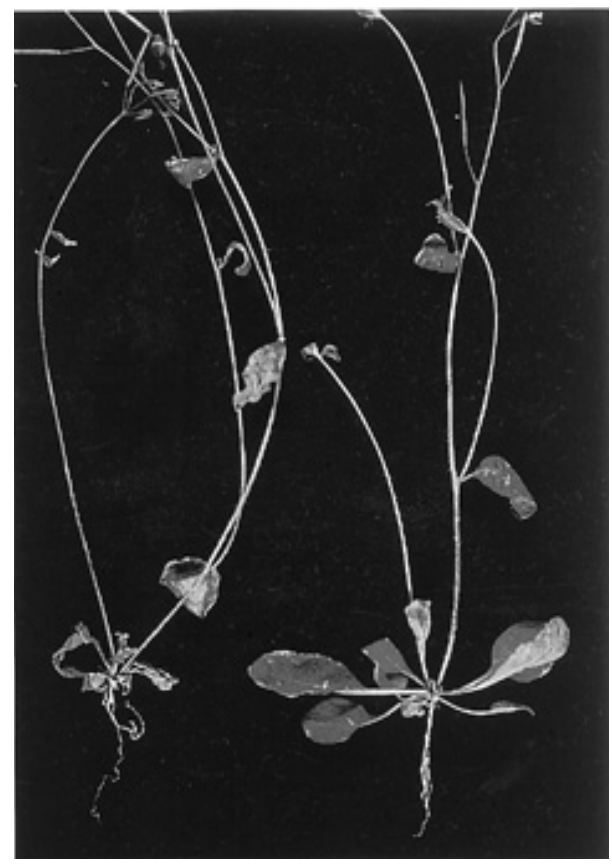

Fig. 4. Resistant and susceptible $\mathrm{F}_{2}$ progeny from the cross between Arabidopsis ecotypes N913 and S96 after inoculation with Ralstonia solanacearum strain Ps95. No symptoms were observed in the resistant plant (right), whereas leaves showed severe wilting in the susceptible plant (left) at 7 days after inoculation.

\section{ACKNOWLEDGMENTS}

This work was supported by a grant to C.-H. Yang from the National Science Council, Taiwan, Republic of China, grant number NSC88-2311B-005-011. We thank S.-T. Hsu and K.-C. Tzeng for their helpful discussion. We also thank the Arabidopsis Biological Resource Center for providing the seed stocks used in this research.

\section{LITERATURE CITED}

1. Acosta, J. C., Gilbert, J. C., and Quinon, V. L. 1964. Heritability of bacterial wilt resistance in tomato. Proc. Am. Soc. Hortic. Sci. 84:455-461.

2. Ausubel, F. M., Brent, R., Kingston, R. E., Moore, D. D., Seidman, J. G., Smith, J. A., and Struhl, K., eds. 1996. Current Protocols in Molecular Biology. John Wiley \& Sons, New York.

3. Bent, A., Kunkel, B. N., Dahlbeck, D., Brown, K. L., Schmidt, R., Giraudat, J., Leung, J., and Staskawicz, B. J. 1994. RPS2 of Arabidopsis thaliana: A leucine-rich repeat class of plant disease resistance genes. Science 265:1856-1860.

4. Boucher, C. A., Barberis, P. A., Trigalet, A. P., and Demery, D. A. 1985. Transposon mutagenesis of Pseudomonas solanacearum: Isolation of Tn5induced avirulent mutants. J. Gen. Microbiol. 131:2449-2457.

5. Büchter, R., Strömberg, A., Schmelzer, E., and Kombrink, E. 1997. Primary structure and expression of acidic (class II) chitinase in potato. Plant Mol. Biol. 35:749-761.

6. Buell, C. R., and Somerville, S. C. 1997. Use of Arabidopsis recombinant inbred lines reveals a monogenic and novel digenic resistance mechanism to Xanthomonas campestris pv. campestris. Plant J. 12:21-29.

7. Culver, J. N., Lindbeck, A. G. C., and Dawson, W. O. 1991. Virus-host interaction: Induction of chlorotic and necrotic responses in plants by tobamoviruses. Annu. Rev. Phytopathol. 29:193-217.

8. Czernic, P., Huang, H. C., and Marco, Y. 1996. Characterization of $h s r 201$ and $h s r 515$, two tobacco genes preferentially expressed during the hypersensitive reaction provoked by phytopathogenic bacteria. Plant Mol. Biol. 31:255-265.

9. Danesh, D., Aarons, S., McGill, G. E., and Young, N. D. 1994. Genetic dissection of oligogenic resistance to bacterial wilt in tomato. Mol. Plant-Microbe Interact. 7:464-471.

10. Deslandes, L., Pileur, F., Liaubet, L., Camut, S., Can, C., Williams, K., Holub, E., Beynon, J., Arlat, M., and Marco, Y. 1998. Genetic characterization of RRS1, a recessive locus in Arabidopsis thaliana that confers resistance to the bacterial soilborne pathogen Ralstonia solanacearum. Mol. Plant-Microbe Interact. 11:659-667.

11. Dixon, R. A., and Lamb, C. J. 1990. Molecular communication in interactions between plants and microbial pathogen. Annu. Rev. Plant Physiol. Plant Mol. Biol. 41:339-367.

12. Grant, M. R., Godiard, L., Straube, E., Ashfield, T., Lewald, J., Sattler, A., Innes, R. W., and Dangl, J. L. 1995. Structure of the Arabidopsis RPM1 gene enabling dual specificity disease resistance. Science 269: 843-846.

13. Hammond-Kosack, K. E., and Jones, J. D. G. 1996. Resistance genedependent plant defense responses. Plant Cell 8:1773-1791.

14. Hayward, A. C. 1991. Biology and epidemiology of bacterial wilt caused by Pseudomonas solanacearum. Annu. Rev. Phytopathol. 29:65-87.

15. Hindges, R., and Slusarenko, A. 1992. cDNA and derived amino acid sequence of a cytosolic $\mathrm{Cu}, \mathrm{Zn}$ superoxide dismutase from Arabidopsis thaliana. Plant Mol. Biol. 18:123-125.

16. Keen, N. T. 1990. Gene-for-gene complementarity in plant-pathogens and symbionts. Annu. Rev. Genet. 24:447-463.

17. Kelman, A. 1954. The relationship of pathogenicity in Pseudomonas solanacearum to colony appearance on a tetrazolium medium. Phytopathology 44:693-695.

18. Kunkel, B. N., Bent, A. F., Dahlbeck, D., Innes, R. W., and Staskawicz, B. J. 1993. RPS2, an Arabidopsis disease resistance locus specifying recognition of Pseudomonas syringae strains expressing the avirulence gene avrRpt2. Plant Cell 5:865-875.

19. Lacomme, C., and Roby, D. 1996. Molecular cloning of a sulfotransferase in Arabidopsis thaliana and regulation during development and in response to infection with pathogenic bacteria. Plant Mol. Biol. 30:995-1008.

20. Levine, A., Tenhaken, R., Dixon, R., and Lamb, C. 1994. $\mathrm{H}_{2} \mathrm{O}_{2}$ from the oxidative burst orchestrates the plant hypersensitive disease resistance response. Cell 79:583-593.

21. Mauch, F., Hadwiger, L. A., and Boller, T. 1988. Antifungal hydrolases in pea tissue. I. Purification and characterization of two chitinase and two $\beta$-1,3-glucanases differentially regulated during development and in response to fungal infection. Plant Physiol. 87:325-333.

22. Mehdy, M. C. 1994. Active oxygen species in plant defense against pathogens. Plant Physiol. 105:467-472

23. Mindrinos, M., Katagiri, F., Yu, G.-L., and Ausubel, F. M. 1994. The A. 
thaliana disease resistance gene RPS2 encodes a protein containing a nucleotide-binding site and leucine-rich repeats. Cell 78:1089-1099.

24. Murashige, T., and Skoog, F. 1962. A revised medium for rapid growth and bioassays with tobacco tissue cultures. Physiol. Plant. 15:473-479.

25. Nürnberger, T., Nennstiel, D., Jabs, T., Sacks, W. R., Hahlbrock, K., and Scheel, D. 1994. High affinity binding of a fungal oligopeptide elicitor to parsley plasma membranes triggers multiple defense responses. Cell 78:449-460.

26. Opena, R. T., Green, S. K., Talekar, N. S., and Chen, J. T. 1988. Genetic improvement of tomato adaptability to the tropics: Progress and future prospects. Pages 70-85 in: Tomato and Pepper Production in the Tropics. S. K. Green, ed. Asian Vegetable Research and Development Center Press, Shanhua, Taiwan.

27. Parker, J. E., Barber, C. E., Fan, M. J., and Daniels, M. J. 1993. Interaction of Xanthomonas campestris with Arabidopsis thaliana: Characterization of a gene from $X$. c. pv. raphani that confers avirulence to most $A$. thaliana accessions. Mol. Plant-Microbe Interact. 6:216-224.

28. Pastuglia, M., Roby, D., Dumas, C., and Cock, J. M. 1997. Rapid induction by wounding and bacterial infection of an $S$ gene family receptorlike kinase gene in Brassica oleracea. Plant Cell 9:49-60.
29. Rogers, E. E., and Ausubel, F. M. 1997. Arabidopsis enhanced disease susceptibility mutants exhibit enhanced susceptibility to several bacterial pathogens and alterations in $P R-1$ gene expression. Plant Cell 9: 305-316.

30. Takahashi, H., Goto, N., and Ehara, Y. 1994. Hypersensitive response in cucumber mosaic virus-inoculated Arabidopsis thaliana. Plant J. 6:369-377.

31. Thoquet, P., Olivier, J., Sperisen, C., Rogowsky, P., Laterrot, H., and Grimsley, N. 1996. Quantitative trait loci determining resistance to bacterial wilt in tomato cultivar Hawaii7996. Mol. Plant-Microbe Interact. 9:826-836.

32. Thoquet, P., Olivier, J., Sperisen, C., Rogowsky, P., Prior, P., Anaïs, G., Mangin, B., Bazin, B., Nazer, R., and Grimsley, N. 1996. Polygenic resistance of tomato plants to bacterial wilt in the French West Indies. Mol. Plant-Microbe Interact. 9:837-842.

33. Uknes, S., Mauch-Mani, B., Moyer, M., Potter, S., Williams, S., Dincher, S., Chandler, D., Slusarenko, A., Ward, E., and Ryals, J. 1992. Acquired resistance in Arabidopsis. Plant Cell 4:645-656.

34. Yang, C.-H., and Ho, G.-D. 1998. Resistance and susceptibility of Arabidopsis thaliana to bacterial wilt caused by Ralstonia solanacearum. Phytopathology 88:330-334. 